\title{
Karakterisasi dan Aplikasi Katalis Nikel-Molibdenum Teremban pada Zeolit Alam Aktif untuk Hidrorengkah Tir Batubara
}

\author{
Dwi Julian Sugianto*), Karna Wijaya, dan Iqmal Tahir \\ Jurusan Kimia, Fakultas Matematika dan Ilmu Pengetahuan Alam, Universitas Gadjah Mada, \\ Sekip Utara, Yogyakarta 55281
}

Diterima 21-03-14 Disetujui 29-01-15

\begin{abstract}
Preparation and characterization of nickel-molybdenum catalysts supported on activated natural zeolite over hydroracking of coal tar have been done. Modification of catalyst was included activation of zeolite by $\mathrm{HCl} 6 \mathrm{~N}$, wet impregnation of NiMo metal and leaching the Ni-Mo from zeolite surfaces with EDTA solution. The parameters of catalyst have been determined i.e acid site number, the ratio of $\mathrm{Si} / \mathrm{Al}$, crystallinity, content of $\mathrm{Ni}-\mathrm{Mo}$ metal, specific surface area, total pore volume, and pore average diameter. The hydrocracking of coal tar was carried out at the optimum temperature $\left(450^{\circ} \mathrm{C}\right)$ by flowing $\mathrm{H}_{2}$ gas $(\mathrm{flow}$ rate of $20 \mathrm{~mL} / \mathrm{min}$ ) on the coal tar with ratio of feed:catalyst was 10:1. The resulting liquid product was analyzed by GC/GCMS.The result showed that catalytic hydrocracking with ZAA catalyst had the highest conversion of liquid products, which were $40.51 \%(w / w)$ compared to Ni-Mo/ZAA catalyst gave $28.61 \%$ and Ni-Mo/ZAA(E) gaves $28.06 \%(w / w)$. The highest light fractions $(67.63 \%(w / w))$ produced by using Ni-Mo/ZAA catalyst and the highest medium fractions were produced over ZAA catalyst which was $36.61 \%(w / w)$ and the highest total conversion on the product with Ni-Mo/ZAA(E) catalyst produced was $50.05 \%(w / w)$. The product analyzed with GC-MS result on the 9th highest peak showed that the hydrocracking products resulted over Ni-Mo/ZAA mostly were phenol and its derivatives.
\end{abstract}

Keywords: catalyst, coal tar, hydrocracking, natural zeolite, nickel-molybdenum

\begin{abstract}
ABSTRAK
Preparasi dan karakterisasi katalis nikel-molibdenum teremban pada zeolit alam aktif untuk hidrorengkah tir batubara sudah dilakukan. Modifikasi katalis meliputi aktivasi zeolit dengan $\mathrm{HCl}$ 6N, impregnasi basah logam Ni-Mo, dan pencucian Ni-Mo dari permukaan zeolit dengan larutan EDTA. Parameter yang dianalisis meliputi jumlah situs asam, rasio Si/Al, kristalinitas, kandungan logam Ni-Mo, luas permukaan spesifik, volume pori total, dan jejari rerata pori. Hidrorengkah tir batubara dilakukan pada temperatur optimum $\left(450^{\circ} \mathrm{C}\right)$ dengan aliran gas $\mathrm{H}_{2}$ (laju alir $20 \mathrm{~mL} / \mathrm{min}$ ) dan rasio tir batubara dengan katalis adalah 10:1. Produk cair yang dihasilkan dianalisis dengan GC/GC-MS. Hidrorengkah katalitik tir batubara dengan katalis ZAA menghasilkan konversi produk cair tertinggi, yaitu 40,51\% (b/b) dibandingkan dengan katalis Ni-Mo/ZAA menghasilkan konversi 28,61\% (b/b) dan katalis Ni-Mo/ZAA(E) menghasilkan konversi 28,06\% (b/b). Fraksi ringan tertinggi $(67,63 \%$ (b/b)) dihasilkan dengan katalis Ni-Mo/ZAA, fraksi sedang tertinggi dihasilkan dengan katalis ZAA yaitu 36,61\% (b/b) sedangkan konversi produk total tertinggi dihasilkan dengan katalis Ni-Mo/ZAA(E) yaitu 50,05\% (b/b). Berdasarkan analisis GC-MS produk cair hasil hidrorengkah dengan katalis Ni-Mo/ZAA, 9 puncak tertinggi pada kromatogram GC-MS tersebut menunjukkan bahwa produk cair tersebut sebagian besar terdiri dari senyawa fenol dan turunannya.
\end{abstract}

Kata Kunci: hidrorengkah, katalis, nikel-molibdenum, tir batubara, zeolit alam

\footnotetext{
*Telp: +6285727484148

Email:djulsu@yahoo.com
} 


\section{PENDAHULUAN}

Tir batubara adalah produk cair dari proses pirolisis batubara yang berwarna hitam kecokelatan dan berwujud cairan kental pada temperatur ruangan. Tir batubara mengandung senyawa hidrokarbon aromatis polosiklik atau Polycyclic Aromatic Hydrocarbons (PAHs), PAHs heterosiklis, fenol, dan BTEX (Benzene, Toluene, Ethylbenzene, Xylenes) (Benhabib et al. 2010). Jiang et al. (2007) melaporkan bahwa senyawa heteroatom yang terkandung dalam tir batubara adalah senyawa siklik yang memiliki atom N, O, dan S. Rachmat (2001) melaporkan bahwa kandungan hasil pirolisis batubara peringkat rendah menghasilkan tiga fraksi yaitu fraksi minyak, fraksi asphaltene, dan fraksi preasphaltene. Menurut Amin et al. (2011), struktur molekul asphaltane mayoritas berupa PAHs sehingga menyebabkan tir batubara memiliki kekentalan yang sangat tinggi. Oleh karena itu, tir batubara belum dapat digunakan langsung sebagai pengganti bahan bakar minyak (BBM).

Struktur molekul tir batubara perlu dipecah agar dapat digunakan sebagai pengganti BBM. Proses pemecahan struktur molekul rantai besar menjadi struktur molekul rantai lebih sederhana dengan bantuan gas $\mathrm{H}_{2}$ disebut proses hydrocracking. Menurut Usui et al. (2004), mekanisme reaksi hidrorengkah senyawa PAHs berawal dari proses hidrogenasi oleh situs asam Lewis pada katalis dan membentuk ion karbonium. Ion karbonium lalu dipecah atau direngkah oleh situs asam Brønsted. Selanjutnya hasil perengkahan dihidrogenasi oleh situs asam Lewis katalis (Raseev 2003).

Katalis yang digunakan dalam penelitian ini adalah katalis nikel-molibdenum yang teremban pada zeolit alam aktif (Ni-Mo/ZAA) dan Ni-Mo/ZAA yang telah dicuci larutan $\operatorname{EDTA}(\mathrm{Ni}-\mathrm{Mo} / \mathrm{ZAA}(\mathrm{E}))$. Katalis yang teremban dalam zeolit alam akan memiliki kestabilan termal dan luas permukaan yang tinggi. Katalis ini termasuk katalis bifungsional, yakni logam Ni dan Mo berperan sebagai situs asam Lewis yang terlibat dalam proses hidrogenasi dan dehidrogenasi sedangkan ZAA berperan sebagai asam Brønsted berfungsi dalam proses perengkahan (Raseev 2003). Pengembanan logam Ni sebagai katalis dan Mo sebagai promotor akan meningkatkan proses hidrogenolisis ikatan C-S dan C-N (Nasikin \& Susanto 2010). Perlakuan pencucian katalis Ni-Mo/ZAA dengan larutan EDTA untuk menghilangkan agregat logam yang terbentuk pada permukaan ZAA sehingga distribusi logam menjadi merata dan menyebabkan peningkatan keasaman katalis (Trisunaryanti et al. 2005).

Penelitian ini bertujuan untuk mempelajari karakteristik katalis $\mathrm{Ni-Mo/ZAA} \mathrm{dan} \mathrm{aplikasinya} \mathrm{pada} \mathrm{reaksi}$ hidrorengkah tir batubara. Karakterisasi sampel meliputi keasaman, luas permukaan spesifik, struktur pori katalis, dan kristalinitas sebelum dan sesudah pencucian dengan EDTA. Aplikasi katalis ditentukan dengan evaluasi selektivitas dan konversi total dari katalis ZAA, Ni-Mo/ ZAA, dan Ni-Mo/ZAA(E) yang paling baik untuk digunakan pada reaksi hidrorengkah tir batubara.

\section{BAHAN DAN METODE}

Bahan-bahan yang digunakan dalam penelitian ini adalah batubara yang berasal dari CV Energi Bio Pelangi dan zeolit alam Gunung Kidul. Bahan-bahan kimia dari Merck yang terdiri dari $\mathrm{Ni}\left(\mathrm{NO}_{3}\right)_{2} .6 \mathrm{H}_{2} \mathrm{O},\left(\mathrm{NH}_{4}\right)_{6} \mathrm{Mo}_{7} \mathrm{O}_{24}$. $4 \mathrm{H}_{2} \mathrm{O}, \mathrm{Na}-\mathrm{EDTA}, \mathrm{HCl} 37 \%, \mathrm{AgNO}_{3}, \mathrm{HF} 48 \%, \mathrm{HNO}_{3} 65 \%$, piridin, amoniak, dan $\mathrm{H}_{3} \mathrm{BO}_{3}$. Bahan-bahan lain terdiri dari gas nitrogen dan gas hidrogen dari PT Samator, kertas saring Whatman 42, akuades, dan akuabides.

Alat-alat yang digunakan dalam penelitian ini adalah peralatan gelas, satu set alat refluks, satu set reaktor hidrorengkah stainless steel, satu set alat penyaring Buchner, oven, pengaduk magnet, hotplate stirrer, furnace, mortar, ayakan, cawan porselen, dan alat timbang analit (Mettler-AT 200). Instrumentasi terdiri dari spektrometer IR (FTIR-8201 PC Shimadzu), Gas Chromatography (GC, Hewlett Pacard 5890 series II), Spektrometer $X$-ray Diffraction (XRD, Shimadzu 6000), Atomic Absorption Spectroscopy (AAS, Perkin-Elmer 3110), alat shaker, dan Surface Area Analyzer (Quantachrome Corporation).

Metode penelitian yang pertama dilakukan adalah aktivasi zeolit alam (ZA). ZA yang lolos ayakan dengan ukuran 100 mesh sebanyak $60 \mathrm{~g}$ direndam dengan akuades dan diaduk dengan pengaduk magnet selama 24 jam. Lalu, ZA disaring dengan penyaring Buchner dan dikeringkan 
pada temperatur $120^{\circ} \mathrm{C}$ selama 3 jam. Setelah itu, ZA dimasukkan ke dalam labu leher tiga alas bulat dan ditambahkan larutan $\mathrm{HCl} 6 \mathrm{~N}$ dengan perbandingan ZA : $\mathrm{HCl}=1: 2(\mathrm{~b} / \mathrm{v})$. Selanjutnya, ZA direfluks pada temperatur $90-95^{\circ} \mathrm{C}$ selama 30 menit. Katalis ZA yang sudah direfluks lalu disaring dan dicuci dengan akuades sampai katalis bersih dari ion $\mathrm{Cl}^{-}$. Indikator keberadaan ion $\mathrm{Cl}^{-}$dalam katalis ditandai dengan pembentukkan endapan putih $(\mathrm{AgCl})$ pada filtrat hasil pencucian jika ditetesi oleh larutan $\mathrm{AgNO}_{3}$. Katalis tersebut dikeringkan dalam oven pada temperatur $120^{\circ} \mathrm{C}$ selama 3 jam dan disebut katalis ZAA. Selanjutnya, katalis ZA dan ZAA akan dianalisis dengan spektrometer FT-IR untuk mengetahui rasio Si/Al (secara kualitatif), absorpsi uap basa (piridin dan amoniak) untuk mengetahui jumlah situs asam permukaan dan total katalis dan dianalisis dengan XRD juga dilakukan untuk menentukan mineralmineral yang terkandung dalam ZA dan ZAA. Katalis ZAA dianalisis dengan metode absorpsi $\mathrm{N}_{2}$ untuk mengetahui luas permukaan bahan.

Setelah proses aktivasi ZAA, dilanjutkan dengan preparasi katalis Ni-Mo/ZAA dan Ni-Mo/ZAA(E). Preparasi katalis Ni-Mo/ZAA dilakukan dengan merefluks larutan logam Ni atau Mo dengan ZAA. Pengembanan logam Ni dan Mo dilakukan bertahap, yakni pengembanan logam Mo terlebih dahulu dan diikuti pengembanan Ni. Total logam yang diembankan adalah $1 \%$ berat katalis dengan perbandingan $\mathrm{Ni}-\mathrm{Mo}=: 1$. Sebanyak 40 g ZAA dimasukkan ke dalam labu leher tiga alas bulat dan ditambahkan 0,368 $\mathrm{g}\left(\mathrm{NH}_{4}\right)_{6} \mathrm{Mo}_{7} \mathrm{O}_{24} \cdot 4 \mathrm{H}_{2} \mathrm{O}$ dan akuabides sampai padatannya terendam semua. Setelah itu, campuran tersebut direfluk dan diaduk dengan pengaduk magnet pada temperatur $90-95^{\circ} \mathrm{C}$ selama 6 jam. Setelah 6 jam, cairan dalam campuran diuapkan pada temperatur $120^{\circ} \mathrm{C}$ dalam oven sampai kering. Selanjutnya dilakukan pengembanan logam Ni. Langkah pengembanan Ni sama seperti pengembanan logam Mo, tetapi yang digunakan adalah $0,991 \mathrm{~g} \mathrm{Ni}\left(\mathrm{NO}_{3}\right)_{2} \cdot 6 \mathrm{H}_{2} \mathrm{O}$.

Katalis yang sudah diembankan logam Ni-Mo dikalsinasi dan direduksi. Proses kalsinasi dilakukan dengan mengaliri gas $\mathrm{N}_{2}$ ke reaktor pada laju alir $10 \mathrm{~mL} /$ menit dengan temperatur $450^{\circ} \mathrm{C}$ selama 3 jam. Setelah itu, katalis direduksi dengan laju alir gas $\mathrm{H}_{2} 10 \mathrm{~mL} /$ menit pada temperatur $400^{\circ} \mathrm{C}$ selama 2 jam. Katalis $\mathrm{Ni}-\mathrm{Mo} / \mathrm{ZAA}$ kemudian dianalisis seperti katalis ZAA.

Preparasi katalis Ni-Mo/ZAA(E) dilakukan dengan pencucian katalis Ni-Mo/ZAA dengan larutan EDTA 0,05M dengan perbandingan katalis dengan larutan EDTA 0,05 M adalah1:10 (b/v). Selanjutnya campuran tersebut diaduk dengan pengaduk magnet pada temperatur kamar selama 2 jam. Setelah itu, katalis disaring dengan kertas saring Whatman 42 dan dikeringkan dalam oven pada temperatur $120^{\circ} \mathrm{C}$ sampai kering. Katalis $\mathrm{Ni}-\mathrm{Mo} / \mathrm{ZAA}(\mathrm{E})$ dianalisis dengan XRD, spektrometer FT-IR, AAS, absorpsi uap basa (piridin dan amoniak) dan absorpsi $\mathrm{N}_{2}$. Absorpsi basa digunakan untuk karakterisasi keasaman sampel, sedangkan absorpsi $\mathrm{N}_{2}$ digunakan untuk karakterisasi porositas dan luas permukaan internal sampel.

Katalis ZAA, Ni-Mo/ZAA, dan Ni-Mo/ZAA(E) yang sudah dipreparasi digunakan untuk proses hidrorengkah katalitik tir batubara. Pertama-tama dilakukan penentuan temperatur optimum dengan proses thermal hydrocracking tir batubara pada temperatur 350, 450, dan $550^{\circ} \mathrm{C}$. Setelah temperatur optimum diperoleh, dilakukan proses hidrorengkah katalitik tir batubara dengan rasio umpan : katalis yang digunakan adalah $10: 1$ (b/b) (10 g tir batubara : $1 \mathrm{~g}$ katalis). Proses hidrorengkah tir batubara dilakukan dengan laju alir gas $\mathrm{H}_{2} 20 \mathrm{~mL} / \mathrm{menit}$ pada temperatur optimum dan dihentikan sampai tidak dihasilkan produk cair lagi. Produk cair yang terkumpul kemudian dianalisis dengan Gas Chromatography (GC) dan untuk produk cair yang memiliki selektivitas fraksi ringan paling banyak dianalisis dengan Gas Chromatography-Mass Spectroscopy (GC-MS).

\section{HASIL DAN PEMBAHASAN}

Karakterisasi Katalis. Perlakuan aktivasi asam ZA akan menghasilkan ZAA. ZA dan ZAA dianalisis dengan spektrometer FT-IR untuk mengetahui rasio $\mathrm{Si} / \mathrm{Al}$ secara kualitatif ZA setelah diaktivasi asam. Spektrogram ZA dan ZAA disajikan pada Gambar 1.

Gambar 1 menunjukkan bahwa ZA memiliki vibrasi regangan asimetris $\mathrm{TO}_{4}(\mathrm{~T}=\mathrm{Si}$ atau $\mathrm{Al})$ pada bilangan gelombang 1049,28 $\mathrm{cm}^{-1}$ sedangkan vibrasi ulur asimetris jalinan internal $\mathrm{TO}_{4}$ pada ZAA muncul pada bilangan 
gelombang 1080,14 $\mathrm{cm}^{-1}$. Pergeseran bilangan gelombang ini menunjukkan perlakuan asam pada ZA menyebabkan dealuminasi sehingga Al dalam kerangka (framework) lepas menjadi Al di luar kerangka (non-framework) zeolit dan menyebabkan ikatan O-Si-O dalam kerangka zeolit semakin seragam. Semakin seragam ikatan O-Si-O dalam kerangka zeolit menyebabkan spektra IR ZAA bergeser ke arah bilangan gelombang yang lebih besar. Hal ini disebabkan ikatan Si-O lebih pendek daripada ikatan Al-O sehingga energi yang diserap oleh ikatan Si-O lebih tinggi dari ikatan Al-O. Semakin pendek ikatan maka kekuatan ikatan akan semakin tinggi, sedangkan semakin panjang ikatan maka kekuatan ikatan akan semakin rendah. Kekuatan ikatan berbanding lurus dengan konstanta gaya (K). Berdasarkan hukum Hooke untuk pegas bervibrasi, K berbanding lurus dengan frekuensi (v) (Pavia et al. 2009). Frekuensi berbanding lurus dengan bilangan gelombang (v). Bilangan gelombang berbanding lurus dengan energi (E). Dengan kata lain, semakin pendek ikatan maka energi yang diserap oleh ikatan tersebut juga akan semakin tinggi.

Pergeseran bilangan gelombang ke lebih besar juga menunjukkan bahwa perlakuan asam menyebabkan peningkatan rasio Si/Al pada ZAA. Pergeseran bilangan gelombang juga terjadi pada daerah vibrasi ulur simetris jalinan eksternal dari $786,96 \mathrm{~cm}^{-1}$ pada ZA menjadi
794,67 $\mathrm{cm}^{-1}$ pada ZAA dan daerah vibrasi ulur simetris jalinan internal $\mathrm{TO}_{4}(\mathrm{~T}=\mathrm{Si}$ or $\mathrm{Al})$ dari 686,66 pada $\mathrm{ZA}$ menjadi $694,37 \mathrm{~cm}^{-1}$ pada ZAA.

Perlakuan asam pada ZA menyebabkan peningkatan rasio $\mathrm{Si} / \mathrm{Al}$ pada $\mathrm{ZAA}$. Peningkatan rasio $\mathrm{Si} / \mathrm{Al}$ mempengaruhi sifat hidrofobisitas zeolit, hal ini dibuktikan dengan terjadi pengurangan intensitas di daerah serapan vibrasi tekuk O-H $\left(\mathrm{H}_{2} \mathrm{O}\right) 1635,34 \mathrm{~cm}^{-1}$. Hal ini dikarenakan situs aktif, $\left[\mathrm{AlO}_{4}\right]^{-}$pada $\mathrm{ZA}$ berkurang sehingga air yang dapat terikat pada zeolit menjadi berkurang. Pertambahan hidrofobisitas ZA juga ditunjukkan oleh penurunan intensitas pada daerah serapan vibrasi ulur O-H dalam $\mathrm{Si}(\mathrm{OH}) \mathrm{Al}$ pada bilangan gelombang $3626,17 \mathrm{~cm}^{-1}$ pada ZAA (Li 2005).

Pengurangan jumlah air dalam zeolit ditunjukkan pada daerah serapan 3400-3600 $\mathrm{cm}^{-1}$ dimana intensitas puncak pada daerah serapan tersebut akan menurun. Oleh karena itu, puncak serapan ZAA pada daerah 1635,34 dan $3425,58 \mathrm{~cm}^{-1}$ menjadi lebih rendah. Dengan kata lain, ZAA lebih hidrofobik daripada ZA dan proses dealuminasi dikatakan berhasil. Proses aktivasi asam dilakukan agar ZA menjadi lebih hidrofobik dan stabilitas termal tinggi sehingga dapat digunakan untuk proses hidrorengkah katalitik.

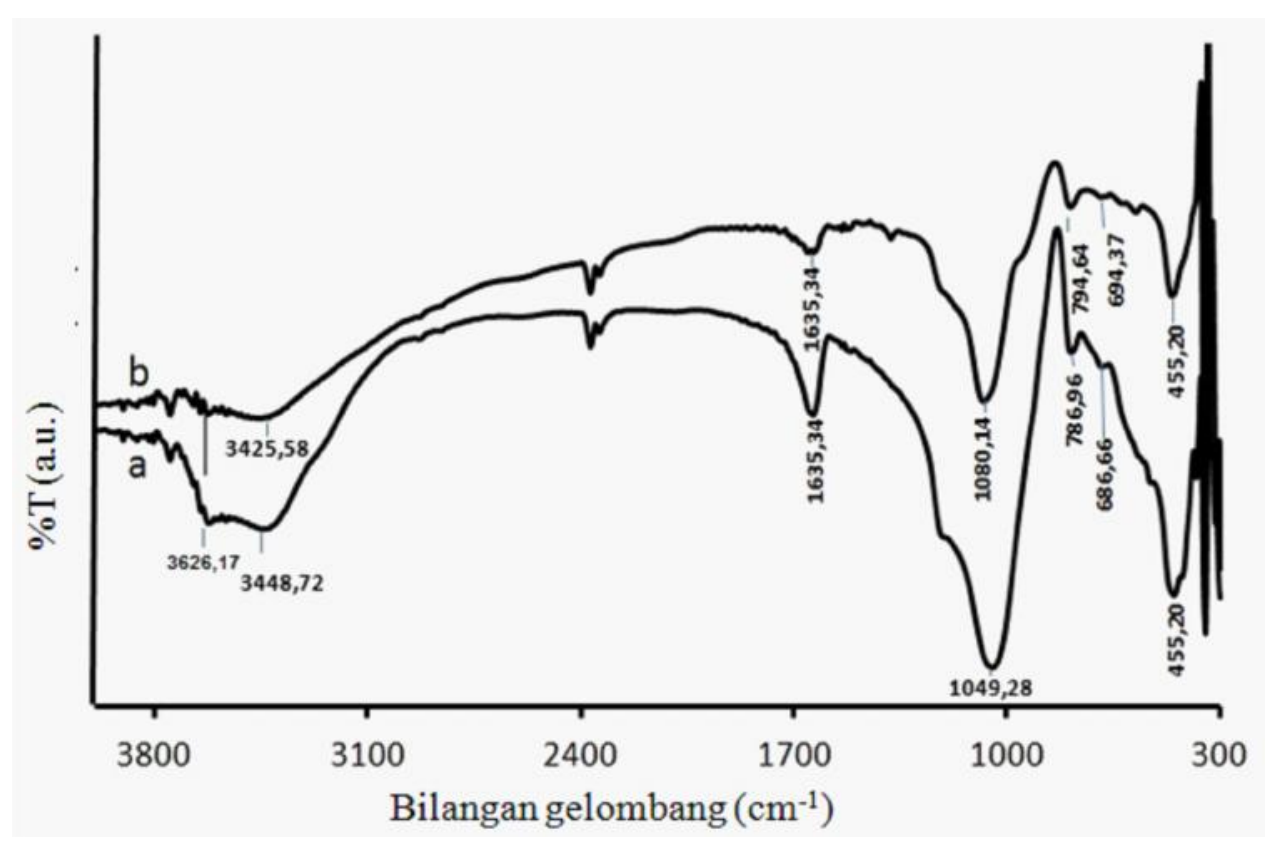

Gambar 1 Spektrogram IR (a) ZA dan (b) ZAA 
Katalis ZA dan ZAA juga dianalisis dengan XRD untuk mengetahui kristalinitas. Difraktogram ZA dan ZAA disajikan pada Gambar 2. Gambar ini menunjukkan bahwa ZA dan ZAA mengandung mineral yang sama yakni mordenite $\left(\left[\mathrm{Na}_{8}\left(\mathrm{H}_{2} \mathrm{O}\right)_{25}\right]\left[\mathrm{Si}_{40} \mathrm{Al}_{8} \mathrm{O}_{96}\right]\right)$ (No. JCPDS 29-1257), clinoptilolite $\left.\left.\left(\left[\mathrm{Na}_{1,84} \mathrm{~K}_{1,76} \mathrm{Mg}_{0,2} \mathrm{Ca}_{1,24} \mathrm{H}_{2} \mathrm{O}\right)_{21,36}\right]_{29,84} \mathrm{Al}_{6,16} \mathrm{O}_{72}\right]\right)$ (No.JCPDS 47-1870) dan quartz ([Si $\left.\mathrm{O}_{6}\right]$ ) (No. JCPDS 050490). Proses aktivasi asam pada ZA menunjukkan terjadi penurunan intesitas mineral clinoptilolite dan peningkatan intensitas mineral quartz. Penurunan intensitas puncak clinoptilolite disebabkan karena terjadi pertukaran ion $\mathrm{Na}^{+}$, $\mathrm{K}^{+}, \mathrm{Mg}^{2+}$, dan $\mathrm{Ca}^{2+}$ oleh ion $\mathrm{H}^{+}$yang berasal dari larutan $\mathrm{HCl} 6 \mathrm{~N}$ dan juga karena terjadinya proses dealuminasi pada ZA. Proses dealuminasi menurunkan ikatan Al-O-Si dalam kerangka zeolit dan menyebabkan ikatan dalam kerangka zeolit menjadi lebih seragam yakni peningkatan ikatan Si-O-Si. Keseragaman ikatan Si-O-Si maka akan meningkatkan keteraturan, di mana semakin tinggi keteraturan maka semakin tinggi kristalinitasnya. Hal ini menyebabkan peningkatan intensitas quartz. Berdasarkan

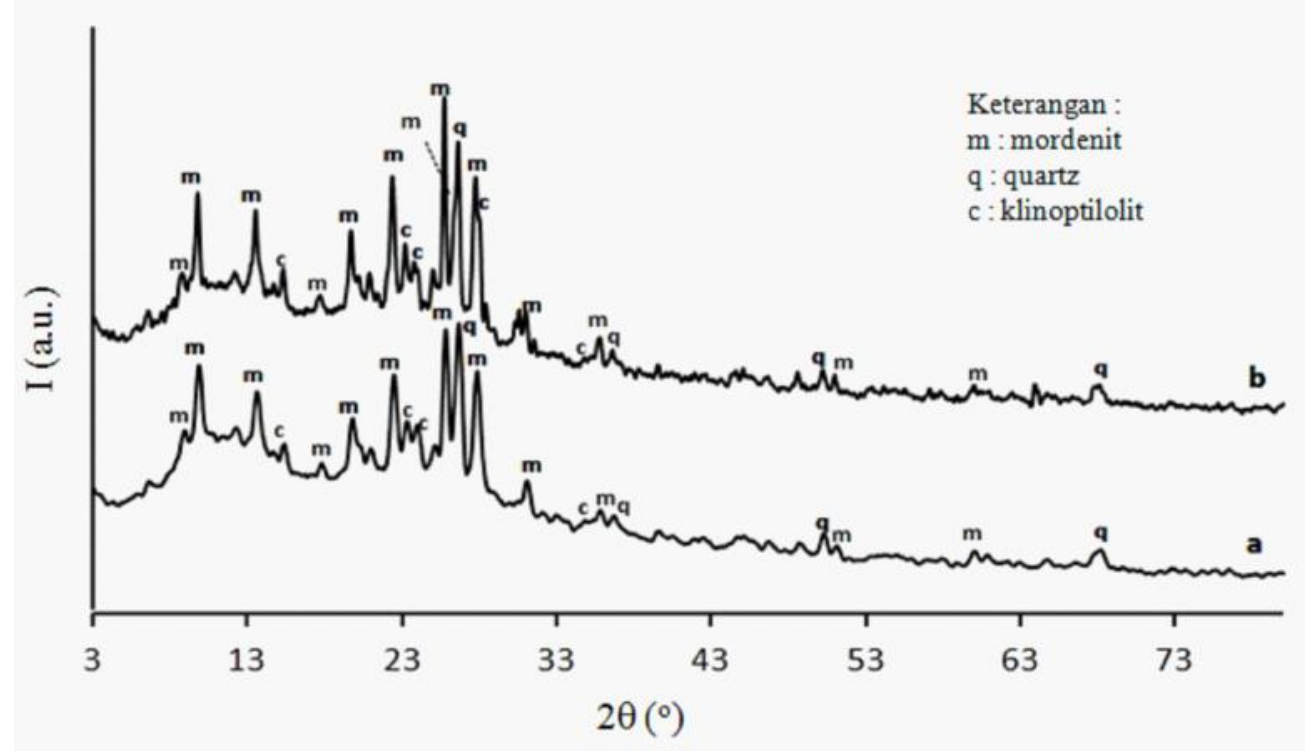

Gambar 2 Difraktogram (a) ZA dan (b) ZAA

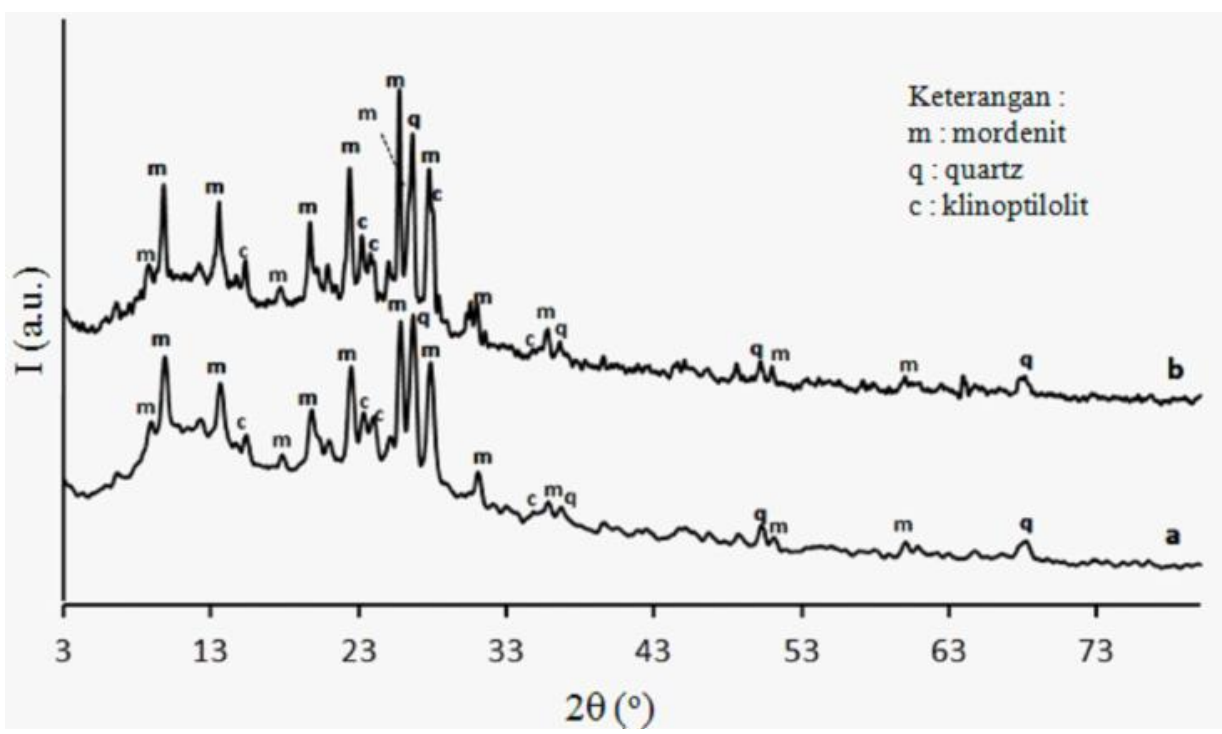

Gambar 3 Difraktogram (a) ZAA dan (b)Ni-Mo/ZAA 
tinjauan difraktogram ZA dan ZAA, pengaruh aktivasi asam akan menyebabkan proses dealuminasi dan dekationasi (Heraldy et al 2003). Hal ini menyebabkan kristalinitas ZAA akan semakin tinggi dan kestabilan termal akan tinggi. Hal ini sesuai tujuan aktivasi dalam penelitian ini yaitu untuk menurunkan mineral clinoptilolite sehingga mineral mordenite menjadi dominan dalam ZAA dan menyebabkan kestabilan termal ZAA lebih tinggi dibandingkan ZA.

Setelah proses aktivasi asam, proses dilanjutkan dengan proses pengembanan logam secara impregnasi basah. Kristalinitas ZAA dan Ni-Mo/ZAA dianalisis dengan XRD. Difraktogram ZAA dan Ni-Mo/ZAA disajikan pada Gambar 3. Gambar 3 menunjukkan bahwa proses pengembanan, kalsinasi, dan reduksi akan mengubah pola difraktogram katalis Ni-Mo/ZAA (Gambar 3b) tetapi tidak signifikan. Salah satu perubahan yang terjadi adalah puncak dari difraktogram Ni-Mo/ZAA lebih lancip dibandingkan ZAA. Hal ini disebabkan karena proses kalsinasi akan menghilangkan pengotor-pengotor yang bersifat amorf sehingga struktur kristal ZAA lebih tinggi dan proses reduksi dilakukan agar logam-logam yang diembankan menjadi bermuatan nol. Oleh karena itu, puncak utama mordenite pada difraktogram katalisNi-Mo/ZAA semakin tinggi. Berdasarkan Gambar 3, puncak-puncak difraktogram ZAA dan Ni-Mo/ZAA tidak berubah secara signifikan. Hal ini membuktikan bahwa pengembanan logam Mo dan Ni yang diembankan ke dalam ZAA tidak akan merusak struktur kristal sesuai dengan penelitian Trisunaryanti et al. (2005).

Perlakuan pencucian Ni-Mo/ZAA dengan larutan EDTA akan menghasilkan katalis Ni-Mo/ZAA(E). Katalis $\mathrm{Ni}-\mathrm{Mo} / \mathrm{ZAA}$ dan Ni-Mo/ZAA(E) dianalis dengan XRD untuk mengetahui kristalinitas katalis. Difraktogram Ni-Mo/ ZAA dan Ni-Mo/ZAA(E) disajikan pada Gambar 4. Pada Gambar 4 terlihat bahwa tidak terdapat perubahan puncakpuncak difraktogram Ni-Mo/ZAA dengan Ni-Mo/ZAA(E) secara signifikan tetapi terdapat peningkatan puncak pada daerah $2 \theta 26,51^{\circ}$ dan penurunan puncak daerah $2 \theta 28,02^{\circ}$ pada difraktogram Ni-Mo/ZAA(E) (Gambar 4a). Puncak pada daerah $2 \theta 26,51^{\circ}$ menyatakan puncak dari quartz sedangkan puncak pada daerah $2 \theta 28,02^{\circ}$ menyatakan puncak dari clinoptilolite. Penurunan kandungan clinoptilolite dimungkinkan karena EDTA membentuk senyawa komplek dengan kation-kation dalam clinoptilolite dan juga menyebabkan keteraturan ikatan Si-O menjadi semakin teratur sehingga kandungan quartz semakin tinggi. Reaksi yang terjadi dalam proses ini disajikan pada Gambar 5 .

Katalis Ni-Mo/ZAA dan Ni-Mo/ZAA(E) dianalisis dengan spektrometer FT-IR untuk mengetahui keberadaan EDTA dalam katalis. Spektrogram IR katalis Ni-Mo/ZAA danNi-Mo/ZAA(E) disajikan pada Gambar 6. Gambar tersebut menunjukkan bahwa spektrogram dari katalisNi-

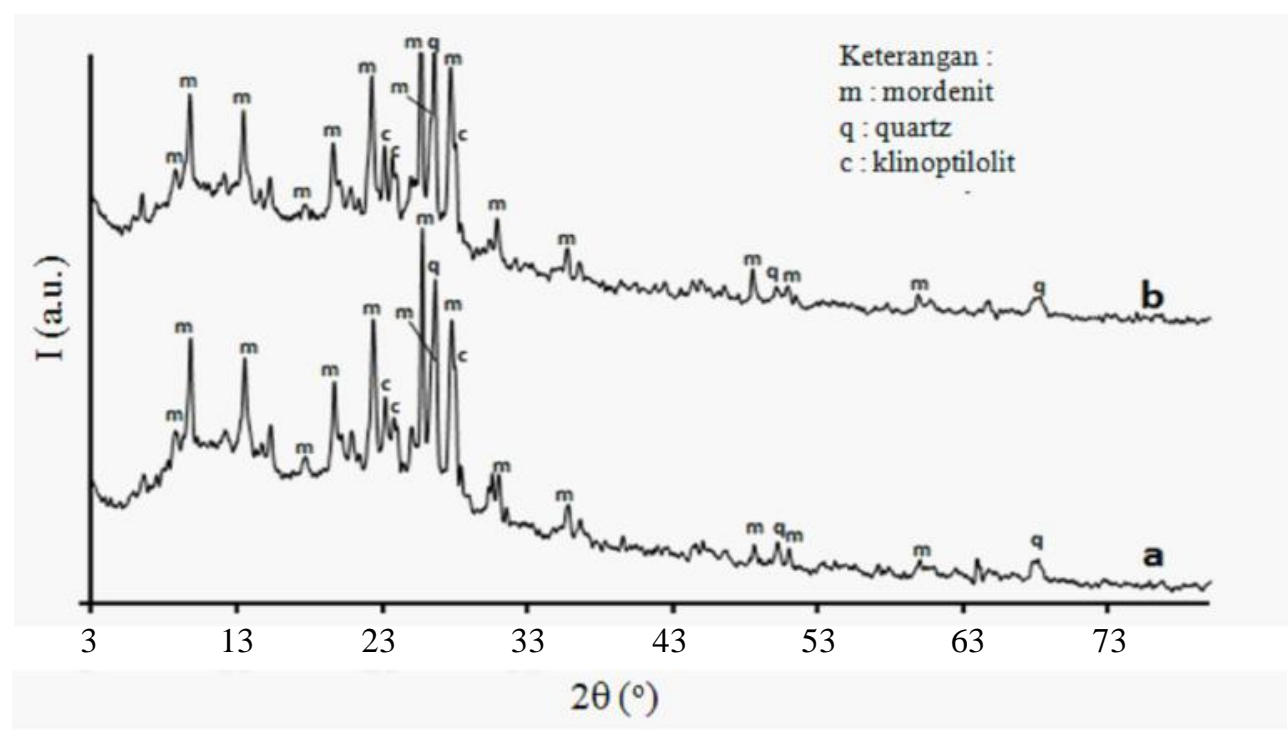

Gambar 4 Difraktogram (a) Ni-Mo/ZAA dan (b) Ni-Mo/ZAA(E) 


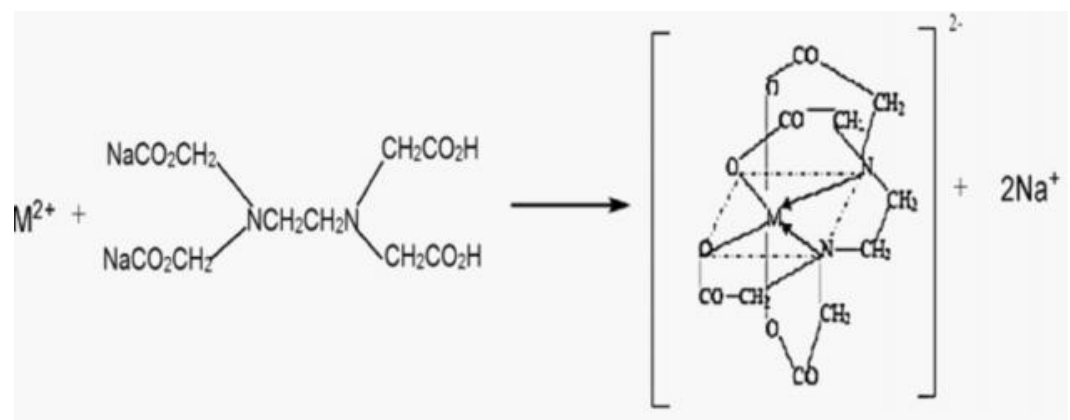

Gambar 5 Reaksi antara logam (M) dengan $\mathrm{Na}_{2} \operatorname{EDTA}(\mathrm{Li} 2013)$

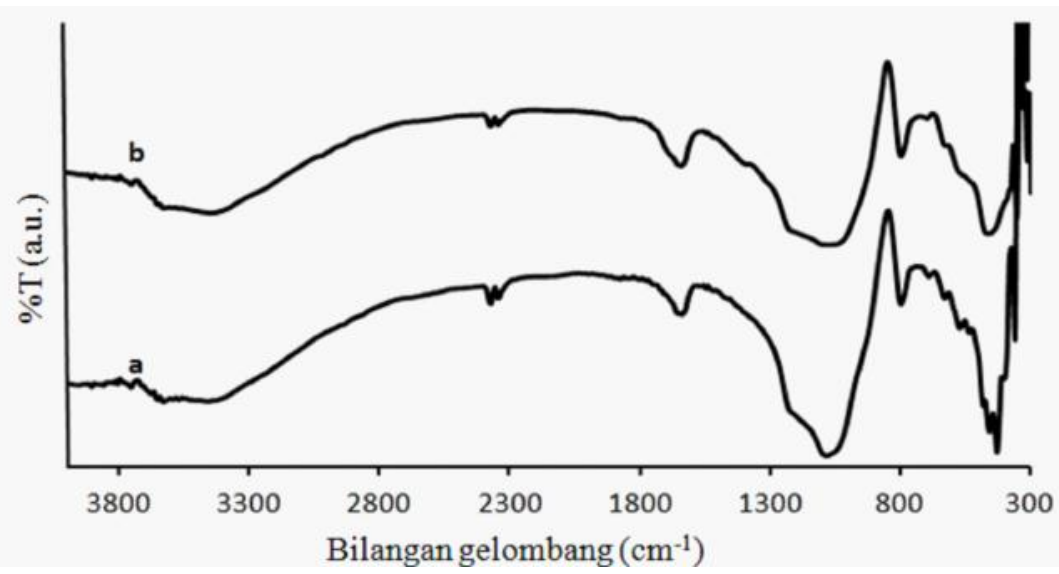

Gambar 6 Spektrogram IR katalis (a) Ni-Mo/ZAA dan (b) Ni-Mo/ZAA(E)

Tabel 1 Kadar logam Ni dan Mo dalam katalis Ni-Mo/ZAA dan Ni-Mo/ZAA(E)

\begin{tabular}{ccccc}
\hline Katalis & \multicolumn{2}{c}{$[\mathrm{Mo}]$} & \multicolumn{2}{c}{$[\mathrm{Ni}]$} \\
\cline { 2 - 5 } & $\mathrm{ppm}$ & $\%(\mathrm{~b} / \mathrm{b})$ & $\mathrm{ppm}$ & $\%(\mathrm{~b} / \mathrm{b})$ \\
\hline Ni-Mo/ZAA & 4241,67 & 0,42 & 3427,42 & 0,16 \\
Ni-Mo/ZAA(E) & 1575,00 & 0,30 & 1106,48 & 0,11 \\
\hline
\end{tabular}

Mo/ZAA dan Ni-Mo/ZAA(E) tidak terdapat perubahan yang signifikan. Spektrogram Ni-Mo/ZAA(E) tidak menunjukkan puncak pada daerah serapan $1700-1750 \mathrm{~cm}^{-}$ ${ }^{1}$ (C=O asam karbosilat), 2850-3000 $\mathrm{cm}^{-1}$ (vibrasi ulur C-H $\mathrm{sp}^{3}$ ), 3100-3500 $\mathrm{cm}^{-1}$ (vibrasi ulur N-H), 2400-3400 $\mathrm{cm}^{-1}$ (vibrasi ulur O-H asam karbosilat) (Pavia et al. 2009). Oleh karena itu, dapat disimpulkan bahwa pencucian katalisNiMo/ZAA dengan EDTA tidak menyebabkan EDTA melekat pada permukaan katalis.

Katalis Ni-Mo/ZAA dan Ni-Mo/ZAA(E) kemudian dianalisis dengan Atomic Absorption Spectroscopy (AAS) untuk menentukan kadar logam Ni dan Mo yang terkandung dalam katalis-katalis tersebut. Kadar logam Mo dan Ni yang terkandung dalam katalis $\mathrm{Ni}-\mathrm{Mo} / \mathrm{ZAA}$ dan
Ni-Mo/ZAA(E) disajikan pada Tabel 1. Tabel tersebut menunjukkan bahwa kadar Ni lebih kecil dari Mo dalam katalis Ni-Mo/ZAA. Hal ini dikarenakan logam Mo diembankan terlebih dahulu sehingga Mo akan membentuk agregat pada permukaan ZAA sehingga logam Ni yang akan masuk ke dalam ZAA menjadi terhalangi dan jumlah Ni yang masuk menjadi lebih kecil dari logam Mo. Kadar logam Mo dan Ni setelah dicuci EDTA mengalami penurunan. Hal ini disebabkan EDTA akan membentuk senyawa komplek dengan logam-logam Mo dan Ni yang belum tereduksi dengan sempurna pada permukaan ZAA, reaksi yang terjadi pada proses tersebut disajikan pada Gambar 5. 


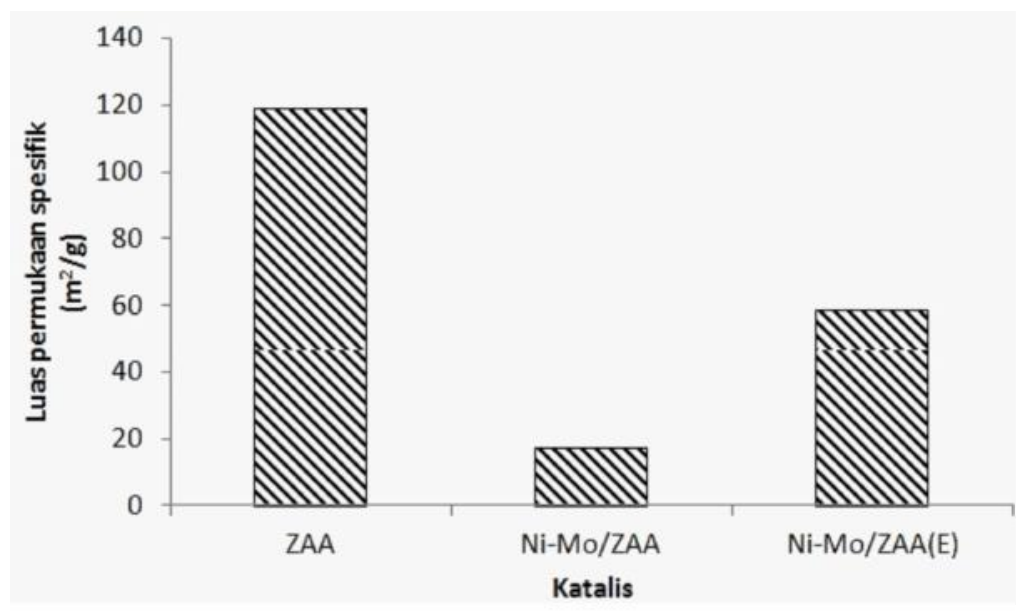

(a)

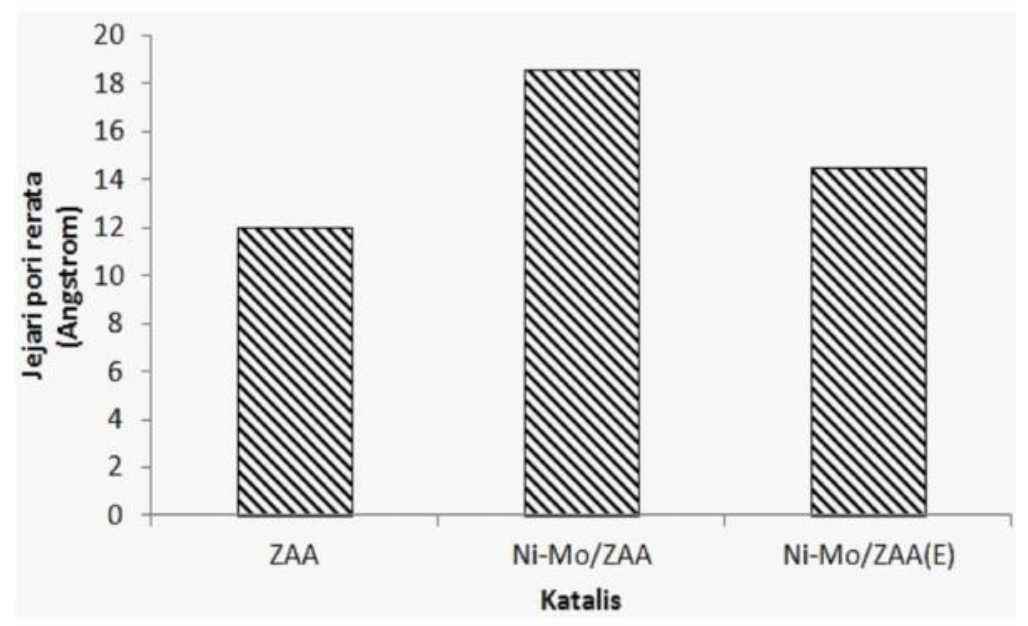

(b)

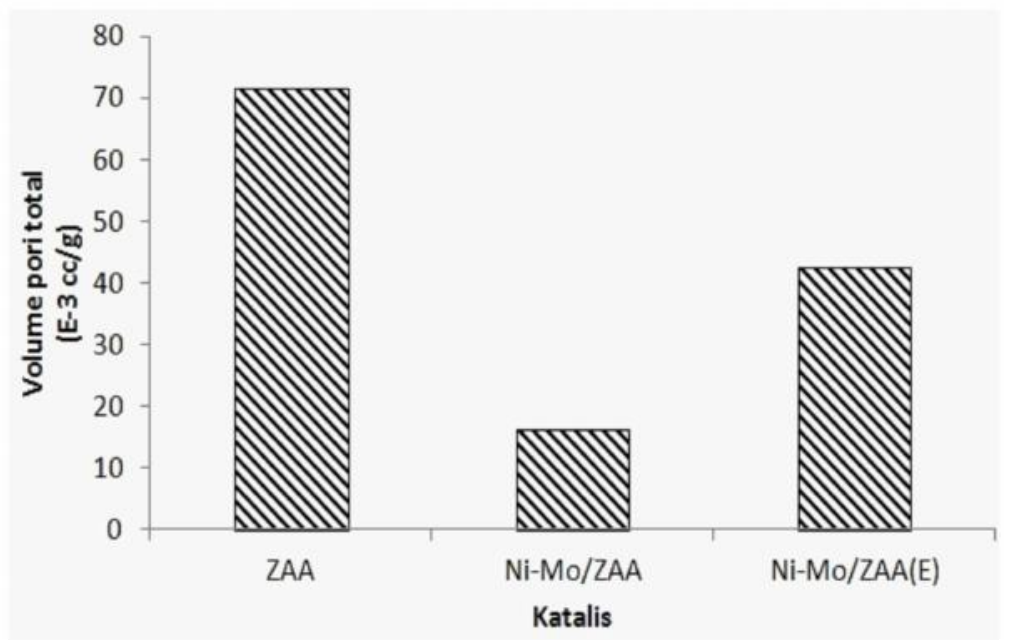

(c)

Gambar 7 (a) Luas permukaan spesifik, (b) jejari rerata pori dan (c) volume pori total katalis ZAA, Ni-Mo/ZAA dan Ni-Mo/ $\mathrm{ZAA}(\mathrm{E})$ 
Luas permukaan spesifik, jejari rerata pori dan volume pori total ditentukan dengan metode absorpsi $\mathrm{N}_{2}$. Luas permukaan spesifik diperoleh menggunakan persamaan BET, sedangkan untuk jejari rerata dan volume pori total diperoleh den gan persamaan BJH. Luas permukaan spesifik, jejari rerata pori dan volume pori total ZAA, Ni-Mo/ZAA danNi-Mo/ZAA(E) disajikan pada Gambar 7.

Berdasarkan Gambar 7, menunjukkan bahwa luas permukaan spesifik dan volume pori katalis-katalis(Gambar 7 a dan c) memiliki pola yang sama. Hal ini disebabkan pada ZAA tidak terdapat logam Mo dan Ni yang menutupi permukaan, sedangkan pada katalis Ni-Mo/ZAA terbentuk agregat logam dari logam yang tereduksi tidak sempurna dan menutupi permukaan ZAA sehingga luas permukaan spesifik dan volume pori total mengalami penurunan (Simseek et al. 2013). Perlakuan pencucian katalis Ni-Mo/ ZAA dengan larutan EDTA menyebabkan agregat logam yang tereduksi tidak sempurna menjadi hilang sehingga luas permukaan spesifik dan volume pori total $\mathrm{Ni}-\mathrm{Mo} /$ ZAA(E) mengalami peningkatan.

Berbeda dengan hal pola luas permukaan spesifik dan volume pori total katalis, jejari rerata pori katalis memiliki pola tertentu. Berdasarkan Gambar 7b, tampak bahwa pengembanan logam Ni-Mo menyebabkan peningkatan jejari rerata pori. Hal ini disebabkan karena agregat logam yang terbentuk pada permukaan ZAA akan membentuk secondary pore dimana pori-pori ini memiliki volume pori yang sangat kecil sehingga diabaikan nilai volume pori tersebut (Simseek et al 2013).

Penentuan jumlah situs asam katalis digunakan metode absorpsi uap basa piridin untuk penentuan jumlah situs asam permukaan dan amoniak untuk penentuan jumlah situs asam total. Jumlah situs asam total dan permukaan dari ZA, ZAA, Ni-Mo/ZAA dan Ni-Mo/ ZAA(E) disajikan pada Gambar 8.

Gambar 8 menunjukkan bahwa secara umum antara jumlah situs asam permukaan dengan total memiliki pola yang hampir sama tetapi berbeda dalam hal ZA dengan ZAA (setelah proses aktivasi). Proses aktivasi asam terlihat akan meningkatkan jumlah situs asam total dan menurunkan jumlah situs asam permukaan. Peningkatan jumlah situs asam total disebabkan pada proses aktivasi asam terjadi proses dekationasi, dimana kation-kation $\left(\mathrm{Mg}^{2+}, \mathrm{Ca}^{2+}, \mathrm{K}^{+}\right)$ yang sebagai pengotor mengalami pertukaran ion dengan ion $\mathrm{H}^{+}$sehingga permukaan ZAA menjadi terbuka dan uap amoniak dapat masuk ke dalam rongga ZAA (Lestari 2010). Penurunan jumlah situs asam permukaan ZAA disebabkan karena proses dealuminasi yang terjadi pada saat proses aktivasi asam. Proses dealuminasi menyebabkan Al kerangka (framework) akan lepas menjadi Al bukan kerangka (non-framework). Pelepasan Al dari kerangka ZAA akan menyebabkan situs aktif (active site) yang bertindak sebagai situs asam Brønsted akan berkurang. Oleh karena itu, jumlah situs asam permukaan ZAA mengalami penurunan.

Jumlah situs asam permukaan dan total dari ZAA, Ni-Mo/ZAA, dan Ni-Mo/ZAA(E) memiliki pola yang sama (Gambar 8). Proses pengembanan logam Ni-Mo akan menyebabkan terbentuknya agregat logam yang tereduksi tidak sempurna pada permukaan katalis sehingga menutupi permukaan. Oleh karena itu, uap piridi dan amoniak hanya dapat berinteraksi dengan logam-logam yang tidak tertutupi oleh agregat logam dan menyebabkan jumlah situs asam baik total dan permukaan Ni-Mo/ZAA mengalami penurunan. Kasus pembentukan agregat logam ini juga terjadi pada katalis $\mathrm{Ni}-\mathrm{Mo} / \gamma-\mathrm{Al}_{2} \mathrm{O}_{3}$ seperti yang dilaporkan oleh Richardson et al. (1996) selain karena pembentukan kokas.

Proses pencucian Ni-Mo/ZAA dengan larutan EDTA menyebabkan jumlah situs asam baik permukaan maupun total mengalami peningkatan. Hal ini disebabkan karena agregat logam membentuk senyawa kompleks dengan EDTA sehingga distribusi logam menjadi merata. Distribusi logam yang merata menyebabkan jumlah situs asam total dan permukaan Ni-Mo/ZAA(E) mengalami peningkatan. Katalis Ni-Mo/ZAA(E) memiliki jumlah situs asam yang tinggi dibandingkan katalis-katalis lain. Hal ini dikarenakan dalam katalis tersebut terdapat 2 situs asam yakni situs asam Lewis dari logam Ni-Mo dan situs Brønsted dari ZAA.

Uji Selektivitas dan Konversi Produk Total. Katalis ZAA, Ni-Mo/ZAA, danNi-Mo/ZAA(E) digunakan untuk katalis hidrorengkah tir batubara. Hal ini dilakukan untuk menentukan selektivitas dan konversi produk total dari masing-masing katalis. Penentuan temperatur optimum produk cair dilakukan dengan proses thermal 


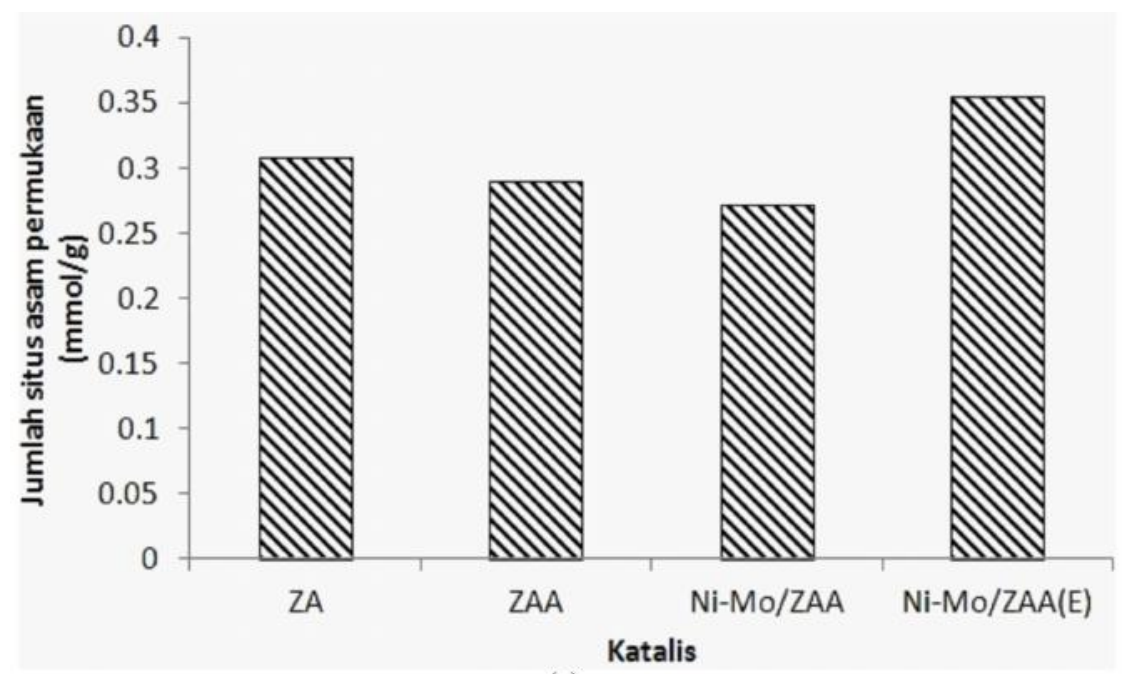

(a)

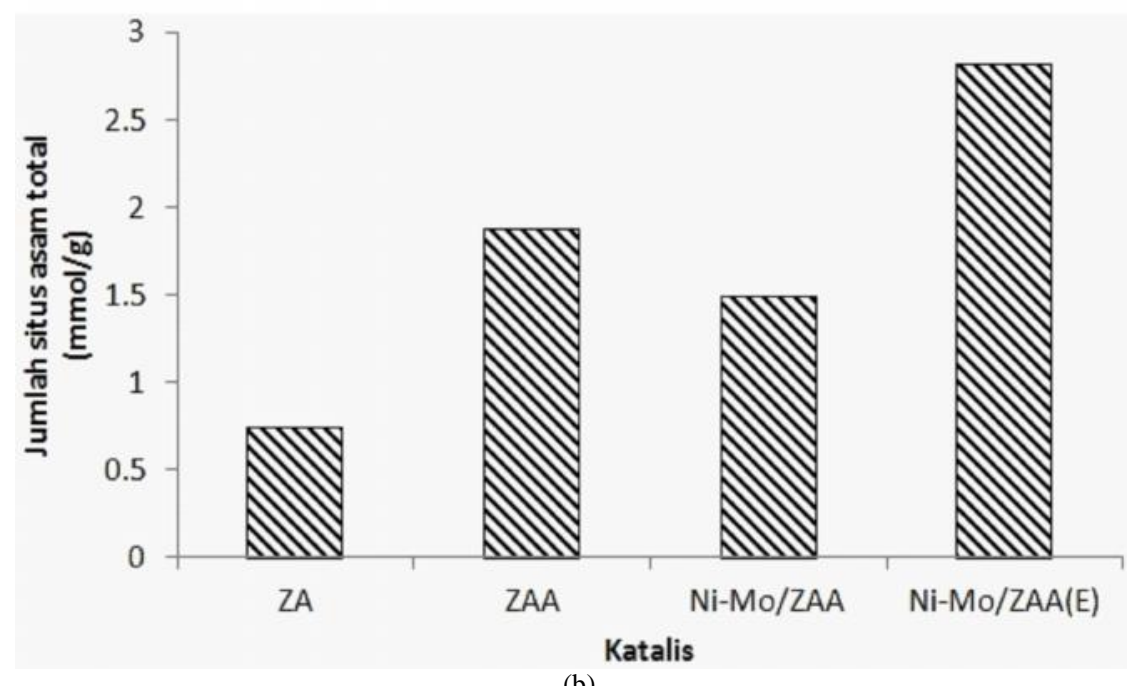

(b)

Gambar 8 Jumlah situs asam (a) permukaan dan (b) total ZA, ZAA, Ni-Mo/ZAA dan Ni-Mo/ZAA(E)

hydrocracking pada temperatur 350,450 , dan $550^{\circ} \mathrm{C}$. Hasil thermal hydrocracking tir batubara disajikan pada Tabel

2. Tabel tersebut menunjukkan bahwa temperatur optimum produk cair dihasilkan pada temperatur $450^{\circ} \mathrm{C}$. Hal ini disebabkan karena pada temperatur $350^{\circ} \mathrm{C}$ sebagian besar senyawa yang terkandung dalam tir batubara memiliki titik didih yang tinggi, sehingga energi yang diperlukan untuk mencapai titik didih belum tercapai.

Pada temperatur $550^{\circ} \mathrm{C}$ dihasilkan konversi total produk yang tertinggi yang disebabkan karena energi sudah mencukupi untuk senyawa tersebut mendidih. Produk cair yang dihasilkan pada temperatur $550^{\circ} \mathrm{C}$ lebih rendah dari temperatur $450^{\circ} \mathrm{C}$, hal ini disebabkan kekurangan pendonor proton (asam Brønsted) yang menyebabkan produk gas yang dihasilkan relatif tinggi sehingga produk cair yang dihasilkan menjadi relatif rendah.

Hidrorengkah katalitik tir batubara dilakukan pada temperatur optimum produk cair yaitu $450^{\circ} \mathrm{C}$ dengan menggunakan katalis ZAA, Ni-Mo/ZAA dan Ni-Mo/ ZAA(E). Hasil hidrorengkah katalitik tir batubara disajikan pada Tabel 3. Tabel tersebut menunjukkan bahwa konversi produk total dari katalisNi-Mo/ZAA(E) dalam hidorengkah tir batubara adalah paling besar yakni 50,05\% (b/b). Konversi produk total katalis ZAA tertinggi kedua dan katalis Ni-Mo/ZAA paling rendah dalam proses 
Tabel 2 Hasil thermal hydrocracking tir batubara

\begin{tabular}{cccc}
\hline $\mathrm{T}\left({ }^{\circ} \mathrm{C}\right)$ & Cair $(\% \mathrm{~b} / \mathrm{b})$ & Gas $(\% \mathrm{~b} / \mathrm{b})$ & Konversi total $(\% \mathrm{~b} / \mathrm{b})$ \\
\hline 350 & 1,86 & 0,17 & 2,03 \\
450 & 23,02 & 9,64 & 40,00 \\
550 & 12,84 & 27,20 & 50,03 \\
\hline
\end{tabular}

Tabel 3 Hasil hidrorengkah katalitik tir batubara

\begin{tabular}{ccccc}
\hline T $\left({ }^{\circ} \mathrm{C}\right)$ & Cair $(\% \mathrm{~b} / \mathrm{b})$ & Kokas $(\% \mathrm{~b} / \mathrm{b})$ & Gas $(\% \mathrm{~b} / \mathrm{b})$ & Konversi total $(\% \mathrm{~b} / \mathrm{b})$ \\
\hline ZAA & 40,51 & 0,56 & 5,60 & 46,67 \\
Ni-Mo/ZAA & 28,61 & 1,61 & 14,10 & 44,31 \\
Ni-Mo/ZAA(E) & 28,06 & 0,02 & 21,86 & 50,05 \\
\hline
\end{tabular}

Tabel 4 Selektivitas fraksi bensin dan diesel dari proses hidrorengkah

\begin{tabular}{lcccccc}
\hline \multirow{2}{*}{ Katalis } & \multicolumn{3}{c}{ Distribusi produk(\% b/b) } & \multicolumn{3}{c}{ Konversi total(\% b/b) } \\
\cline { 2 - 7 } & Fraksi ringan & Fraksi sedang & Fraksi berat & Fraksi ringan & Fraksi sedang & Fraksi berat \\
\hline ZAA & 52,44 & 36,61 & 10,95 & 21,24 & 14,83 & 4,44 \\
i-Mo/ZAA & 67,63 & 27,51 & 4,86 & 19,35 & 7,87 & 1,39 \\
Mo/ZAA(E) & 63,86 & 29,35 & 6,80 & 17,92 & 8,23 & 1,91 \\
ZAA & 52,44 & 36,61 & 10,95 & 21,24 & 14,83 & 4,44 \\
\hline
\end{tabular}

hidrorengkah katalitik tersebut. Luas permukaan spesifik, jumlah situs asam, dan pori-pori mempengaruhi konversi produk total. Konversi produk total dipengaruhi oleh jumlah situs asam permukaan katalis. Katalis Ni-Mo/ ZAA(E) memiliki jumlah situs asam permukaan yang tinggi (Gambar 8a) sehingga jumlah proton yang tersedia pada permukaan katalis Ni-Mo/ZAA(E) paling tinggi dan proses hidrorengkah yang terjadi akan semakin besar. Oleh karena itu, konversi produk total dari katalis Ni-Mo/ZAA(E) paling tinggi. Dengan kata lain, jumlah situs asam permukaan katalis berbanding lurus dengan konversi produk total dan hal ini sesuai dengan penelitian Saerodji (2013).

Jumlah situs asam permukaan katalis juga berpengaruh dalam hal pembentukkan produk kokas dan gas. Menurut Eberly et al. (1966), pembentukkan kokas pada permukaan katalis disebabkan kekurangan proton $(\mathrm{H})$ pada permukaan katalis. Dengan kata lain, jumlah situs asam permukaan Ni-Mo/ZAA yang relatif rendah menyebabkan pembentukkan kokas semakin tinggi. Pembentukkan gas dikarenakan pada permukaan katalis memiliki kelimpahan proton. Katalis Ni-Mo/ZAA(E) memiliiki jumlah situs asam permukaan yang tinggi sehingga produk gas yang dihasilkan paling tinggi.

Produk cair tertinggi dihasilkan oleh katalis ZAA. Hal ini disebabkan luas permukaan spesifik ZAA paling tinggi, sehingga kontak antara umpan dengan katalis akan semakin besar. Dengan kata lain, kemungkinan terjadi proses hidrogenasi dan perengkahan pada permukaan katalis ZAA sangat tinggi dibandingkan katalis Ni-Mo/ ZAA dan Ni-Mo/ZAA(E). Produk cair yang dihasilkan dengan menggunakan katalis Ni-Mo/ZAA(E) paling kecil tetapi tidak berbeda signifikan dengan produk cair dari NiMo/ZAA. Hal ini dikarenakan banyak gas yang yang terbentuk dengan katalis Ni-Mo/ZAA(E), sedangkan produk cair yang dihasilkan dengan menggunakan katalis $\mathrm{Ni}-\mathrm{Mo} / \mathrm{ZAA}$ relatif rendah karena disebabkan permukaan katalis tertutupi kokas sehingga kinerja katalis menurun. Fenomena serupa terjadi pada katalis $\mathrm{Ni}-\mathrm{Mo} / \gamma-\mathrm{Al}_{2} \mathrm{O}_{3}$ (Richardson et al. 1996) yang melaporkan faktor pembentukan kokas ini yang cukup berpengaruh pada aktivitas katalis.

Selektivitas katalis dianalisis dengan menggunakan kromatografi gas (gas chromatography /GC) dan dilihat dari fraksi ringan, sedang dan berat yang dihasilkan. Selektivitas katalis diperoleh dari perhitungan luas permukaan kromatogram produk cair dengan waktu retensi (retention time) dari bensin dan diesel. Waktu retensi dari fraksi ringan (bensin) adalah 0-10 menit, sedangkan waktu retensi fraksi sedang (diesel) adalah 11-20 menit (Saerodji 2013). Data selektivitas produk cair disajikan pada Tabel 4. 
Tabel 5 Sembilan puncak tertinggi hasil analisis GC-MS produk hidorengkah tir batubara dengan katalis Ni-Mo/ZAA

\begin{tabular}{cccc}
\hline Puncak ke- & Waktu retensi (menit) & \% Area (\%) & Senyawa \\
\hline 4 & 12,16 & 11,29 & fenol \\
5 & 12,24 & 4,23 & asam bensesulfonat \\
13 & 14,69 & 7,19 & 2 -metil-fenol \\
14 & 15,59 & 12,33 & 3 -metil-fenol \\
26 & 17,92 & 5,70 & 2,3 -dimetil-fenol \\
30 & 18,64 & 5,31 & 3 -etil-fenol \\
35 & 19,39 & 2,46 & dodekana \\
66 & 26,05 & 2,41 & 2,6-dimetil-naftalen \\
98 & 49,19 & 3,64 & di-n-octylphtalate \\
\hline
\end{tabular}

Tabel 4 menunjukkan bahwa fraksi ringan tertinggi dihasilkan dari proses perengkahan dengan katalis $\mathrm{Ni}-\mathrm{Mo} /$ ZAA dan fraksi ringan terendah dihasilkan oleh katalis ZAA. Menurut Fărcasiu et al. (1990), selektivitas katalis terhadap produk cair dipengaruhi oleh beberapa faktor salah satunya adalah ukuran jejari pori katalis. Gambar 7b menunjukkan bahwa jejari rerata pori katalis yang paling besar adalah katalis Ni-Mo/ZAA sedangkan yang paling kecil adalah katalis ZAA. Semakin besar ukuran pori maka semakin besar senyawa hidrokarbon yang dapat terpecah menjadi senyawa hidrokarbon yang lebih sederhana. Hal ini menjelaskan alasan penggunaan katalis Ni-Mo/ZAA akan memberikan hasil fraksi bensin semakin banyak.

Dalam Tabel 4 terlihat bahwa distribusi produk cair pada proses hidrorengkah katalitik membentuk sebuah pola. Pola tersebut menyatakan bahwa semakin besar fraksi ringan yang dihasilkan maka akan semakin kecil fraksi berat yang dihasilkan dan sebaliknya.

Produk cair hasil hidrorengkah dengan katalis Ni-Mo/ ZAA dianalisis dengan GC-MS untuk mengetahui kemungkinan senyawa dalam poroduk tersebut. Sembilan puncak tertinggi hasil analisis GC-MS produk hidrorengkah tir batubara dengan katalis Ni-Mo/ZAA disajikan pada Tabel 5.

Tabel 5 menunjukkan bahwa sebagian besar senyawa yang terkandung dalam produk cair hasil perengkahan dengan katalis Ni-Mo/ZAA adalah senyawa siklik seperti fenol, turunan fenol dan naftalena. Hal ini membuktikan bahwa perengkahan senyawa yang memiliki struktur yang relatif besar (asphaltane) dalam tir batubara akan menghasilkan senyawa siklik yang lebih sederhana atau senyawa monosiklik. Tabel tersebut juga menunjukkan bahwa fraksi ringan $\left(\mathrm{C}_{4}-\mathrm{C}_{12}\right)$ sebagian besar mengandung senyawa fenol dan turunannya sedangkan fraksi sedang $\left(\mathrm{C}_{13}-\mathrm{C}_{20}\right)$ sebagian besar mengandung senyawa turunan naftalane. Fraksi berat sebagian besar mengandung senyawa di-n-octyl phthalate.

\section{SIMPULAN}

Berdasarkan hasil penelitian ini dapat disimpulkan bahwa pencucian katalis Ni-Mo/ZAA dengan larutan EDTA akan menyebabkan peningkatan keasaman total dan permukaan, kristalinitas katalis, luas permukaan spesifik, volume pori dan penurunan jejari rerata pori. Konversi produksi fraksi ringan total tertinggi dihasilkan oleh katalis ZAA untuk proses hidrorengkah tir batubara pada temperatur $450^{\circ} \mathrm{C}$. Untuk katalis Ni-Mo/ZAA dan Ni-Mo/ $\mathrm{ZAA}(\mathrm{E})$ menghasilkan konversi fraksi ringan yang relatif lebih rendah.

\section{UCAPAN TERIMA KASIH}

Penelitian ini didukung oleh dana hibah DIKTI program kreativitas mahasiswa bidang penelitian (PKMP) tahun 2013.

\section{DAFTAR PUSTAKA}

Amin, S.J., Nikooee, E., Ghatee., Ayatollahi,S.H.,Alamdai, A \& Sedghamiz, T. 2011. Investigating the effect of different asphaltene structures on surface topography and wettability alteration. Appl. Surf. Sci 257: 83418349.

Benhabib, K., Faure, P., Sardin, M \& Simonnot, M.O. 2010. Characteristics of a solid coal tar sampled from a contaminated soil and of the organics transferred into water. J. Fuel 89: 352-359.

Eberly, E.P, Jr., Kimberlin, N.C., Miller, H.W \& Drushel, V.H. 1966. Coke formation on silica-alumina cracking catalyst. Ind. Eng. Chem. Process Des. Dev 5: 193197. 
Fărcasiu, D., Hutchitson, J \& Li, L. 1990. An analysis of factor that influence shape selectivity in the cracking of long-chain alkanes on zeolites catalyst. J. Catal 122: 34-43.

Heraldy, E., Hisyam, S.W \& Sulistiyono. 2003. Characterization and Activation of Natural Zeolite From Ponorogo. Indo. J. Chem 3: 91-97.

Jiang, J., Wang, Q., Wang, Y., Tong, W \& Xiao, B. 2007. GC/MS analysis of coal tar composition produced from coal pyrolysis. Bull. Chem. Soc. Ethiop 21: 229-240.

Lestari, Y.D. 2010. Kajian modifikasi dan karakterisasi zeolit dari berbagai negara. Profesionalisme peneliti dan pendidik dalam riset dan pembelajaran yang berkualitas dan berkarakter. Proseding Nasional Kimia dan Pendidikan Kimia. Yogyakarta, 30 Oktober 2010.

Li, G. 2005. FT-IR studies of zeolite material : Characterization and environmental applications, Dissertation, Mathematic and Natural Science Faculty. Iowa: University of Iowa.

Nasikin, M \& Susanto, H, B. 2010. Katalisis heterogen. Jakarta: UI-Press.

Pavia, D.L., Lampman, M.G., Kriz,S.G \& Vyvyan, R.J. 2009. Introduction to spectroscopy, $4^{\text {th }}$. Sidney: Brooks/Cole.

Rachmat, A. 2001. Pengaruh temperatur pirolisis dan jenis pelarut pada ektraksi terhadap produk cair batubara peringkat rendah. Tesis Pasasarjana. Fakultas Matematika dan Ilmu Pengetahuan Alam. Yogyakarta: Universitas Gadjah Mada.
Raseev, S. 2003. Thermal and catalytic processes in petroleum refining. New York: Marcel Dekker, Inc. 681694.

Richardson, S.M, Nagaishi, H \& Graym M.R. 1996. Initial coke deposition on a $\mathrm{NiMo} / \mathrm{a}-\mathrm{Al}_{2} \mathrm{O}_{3}$ bitumen hydroprocessing catalyst. Ind. Eng. Chem. Res 35: 3940-3950.

Saerodji, G.M. 2013. Preparasi, karakterisasi dan uji aktivitas katalis logam Ni, Co, NiMo, dan CoMo yang diembankan pada zeolit alam aktif untuk hidrorengkah plastik polietilena menjadi fraksi bensin dan diesel. Skripsi Sarjana. Fakultas Matematika dan Ilmu Pengetahuan Alam. Yogyakarta: Universitas Gadjah Mada.

Simseek, B,E., Ozdemir, E \& Beker, U. 2013. Zeolite supported mono- and bimetallicoxides: Promising adsorbents for removal of As (V) in aqeous solutions. J. Chem. Eng 220: 02-411.

Trisunaryanti, W., Triwahyuni, E \& Sudiono, S. 2005. Preparasi, modifikasi dan karakterisasi katalis Ni-Mo/ zeolit alam dan Mo-Ni/zeolit alam. J. Teknoin 10: 269282.

Usui, K., Kidena, K., Murata, S., Nomura, M \& Trisunaryanti, W. 2004. Catalytic Hydrocracking of petroleum-derived asphaltenes by transition metalloaded zeolite catalysts. J. Fuel 83: 1899-1906. 